\title{
Pelaksanaan Program Manajemen Pasien dengan Risiko Jatuh di Rumah Sakit
}

\section{The Implementation of Patient Fall Risk Management Program in Hospital}

\author{
Sugeng Budiono1, Arief Alamsyah², Tri Wahyu $S^{3}$ \\ ${ }^{1}$ Rumah Sakit Umum Daerah Yowari Kabupaten Jayapura \\ 2Program Studi Magister Manajemen Rumah Sakit Fakultas Kedokteran Universitas Brawijaya Malang \\ ${ }^{3}$ Rumah Sakit Islam Universitas Islam Malang
}

\begin{abstract}
ABSTRAK
Manajemen pasien dengan risiko jatuh merupakan salah satu tujuan keselamatan pasien, dan pada Rumah Sakit Islam Unisma Malang, masih menempati urutan ke empat dari seluruh kejadian yang tidak di inginkan (KTD). Sejak dimulainya program patient safety bulan Januari 2013 belum ada suatu kebijakan atau program manajemen pasien risiko jatuh termasuk Standar Prosedur Operasional (SPO). Penelitian ini merupakan bentuk kaji tindak manajemen risiko pasien jatuh di Rumah Sakit Islam Unisma Malang. Kajian diawali dengan analisis akar masalah, penetapan solusi terpilih dan uji program. Uji program dilakukan terhadap penerapan screening pasien dengan risiko jatuh. Instrumen menggunakan observasi dan form screening pasien jatuh. Hasil menunjukkan sebagian besar petugas atau perawat telah melaksanakan dengan baik program manajemen pasien jatuh yang meliputi: screening, pemasangan gelang identitas risiko jatuh, edukasi pasien dan keluarga tentang menggunakan leaflet edukasi, pengelolaan pasien risiko jatuh, penanganan pasien jatuh dan pelaporan insiden. Penetapan kebijakan dan impementasi prosedur yang diikuti supervisi dan monitoring lebih menjamin keterlaksanaan program.
\end{abstract}

Kata Kunci: Kejadian tidak diinginkan (KTD), manajemen risiko pasien jatuh, patient safety

\begin{abstract}
Management of patients with the risk of falling is one of the goals of patient safety, and in Unisma Islamic Hospital Malang, patient falls incidence data obtained still ranks fourth of all unwanted incidents. Since the commencement of the patient safety program in January 2013, there has been no policy or a program management on patient fall risk management including the Standard Operating Procedures. This study is a follow-form review of patient fall risk management in Unisma Islamic Hospital Malang. The study begins with an analysis towards the root of the problem, the determination of selected solutions and program testing. Program testing was conducted on the application of screening patients with risk of falling. The instrument used observation and falling patient screening form. The results show that the majority of officers or nurses have executed well the patient falls management programs including screening, mounting of falling risk identification bracelet, educating patients and families about using education leaflets, the management of patients at risk of falling, falling patient handling and incident reporting. Policy and procedure establishment followed with implementation of supervision and monitoring will better ensure the adherence of the program.
\end{abstract}

Keywords: Patient fall risk management, patient safety, unwanted incidence

Jurnal Kedokteran Brawijaya, Vol. 28, Suplemen No. 1, 2014: Sugeng Budiono. Program Studi Magister Manajemen Rumah Sakit Fakultas Kedokteran Universitas Brawijaya Malang, Jl. Veteran Malang 65142 Tel. (0341) 568989 Email: ayah.izza@yahoo.com 


\section{PENDAHULUAN}

Pelayanan kesehatan di Rumah Sakit merupakan pemenuhan kebutuhan dan tuntutan dari pemakai jasa pelayanan (pasien) yang mengharapkan penyembuhan dan pemulihan yang berkualitas dan penyediaan pelayanan kesehatan yang nyaman dan aman. Pelayanan tidak lagi hanya berfokus pada kepuasan pasien tetapi lebih penting lagi adalah keselamatan pasien (patient safety). Harapan pelayanan profesional yang bermutu tinggi yang berfokus pada keselamatan (safety) dan kepuasan pasien dapat terlaksana.

Program Keselamatan Pasien (patient safety) adalah suatu sistem yang memastikan rumah sakit membuat asuhan pasien menjadi lebih aman. Komponen yang termasuk di dalamnya adalah: pengkajian risiko, identifikasi dan pengelolan risiko pasien, pelaporan dan analisa insiden, kemampuan belajar dari insiden, dan tindak lanjutnya serta implementasi solusi untuk meminimalkan timbulnya risiko. Sistem ini mencegah terjadinya cedera yang disebabkan oleh kesalahan akibat melaksanakan suatu tindakan atau tidak mengambil tindakan yang seharusnya diambil (1).

Kajian sebelumnya membuktikan bahwa $50 \%$ kematian akibat cidera medis sebenarnya dapat dicegah. Untuk mencegah kejadian yang tidak diharapkan (KTD) perlu dibangun budaya keselamatan pasien di rumah sakit (2). Dalam upaya mencegah terjadinya kejadian yang tidak diharapkan pada pasien yang dirawat perlu ditumbuh kembangkan kepemimpinan dan budaya rumah sakit yang mencakup keselamatan pasien dan peningkatan mutu pelayanan (3). Setiap rumah sakit harus menerapkan beberapa syarat yang ditetapkan untuk keselamatan pasien yaitu six patient safety goals atau enam sasaran keselamatan pasien, meliputi ketepatan identifikasi pasien, peningkatan komunikasi yang efektif, peningkatan keamanan obat yang perlu diwaspadai, kepastian tepat lokasi-tepat prosedur-tepat pasien post operasi, pengurangan risiko infeksi, dan pengurangan risiko pasien jatuh (2).

Berdasarkan laporan tahunan 2012 di Rumah Sakit Islam Unisma Malang, diperoleh data bahwa kejadian pasien jatuh masih menempati urutan ke empat dari seluruh kejadian yang tidak di inginkan (KTD). Selain itu sejak dimulainya program patient safety bulan Januari 2013 belum dilakukan penyusunan suatu kebijakan atau program manajemen pasien risiko jatuh termasuk Standar Prosedur Operasional (SPO) manajemen pencegahan pasien risiko jatuh (3-6).

Upaya untuk mengantisipasi dan mencegah terjadinya pasien jatuh dengan atau tanpa cidera sangat diperlukan. Rumah sakit wajib melakukan penanganan pasien risiko jatuh yang dapat dimulai dari pengkajian di awal pasien masuk maupun pengkajian ulang secara berkala, termasuk risiko potensial yang berhubungan dengan jadwal pemberian obat serta mengambil tindakan untuk mengurangi semua risiko yang telah diidentifikasikan tersebut. Manajemen risiko pasien jatuh ini dapat dilaksanakan sejak pasien mendaftar hingga pasien pulang. Kajian ini dilakukan untuk mengidentifikasi akar masalah penyebab risiko pasien jatuh, mengembangkan alternatif solusi dan melakukan uji dari alternatif solusi tersebut

\section{METODE}

Analisis akar masalah dilakukan menggunakan diagram Ishikawa (fishbone analysis), berdasarkan data sekunder maupun primer yang didapatkan dari observasi dan wawancara. Akar masalah yang telah dikonfirmasi kemudian dijadikan sebagai dasar dalam memilih alternatif solusi yang dilakukan melalui brain storming dan focused group discussion dengan para pelaksana program.

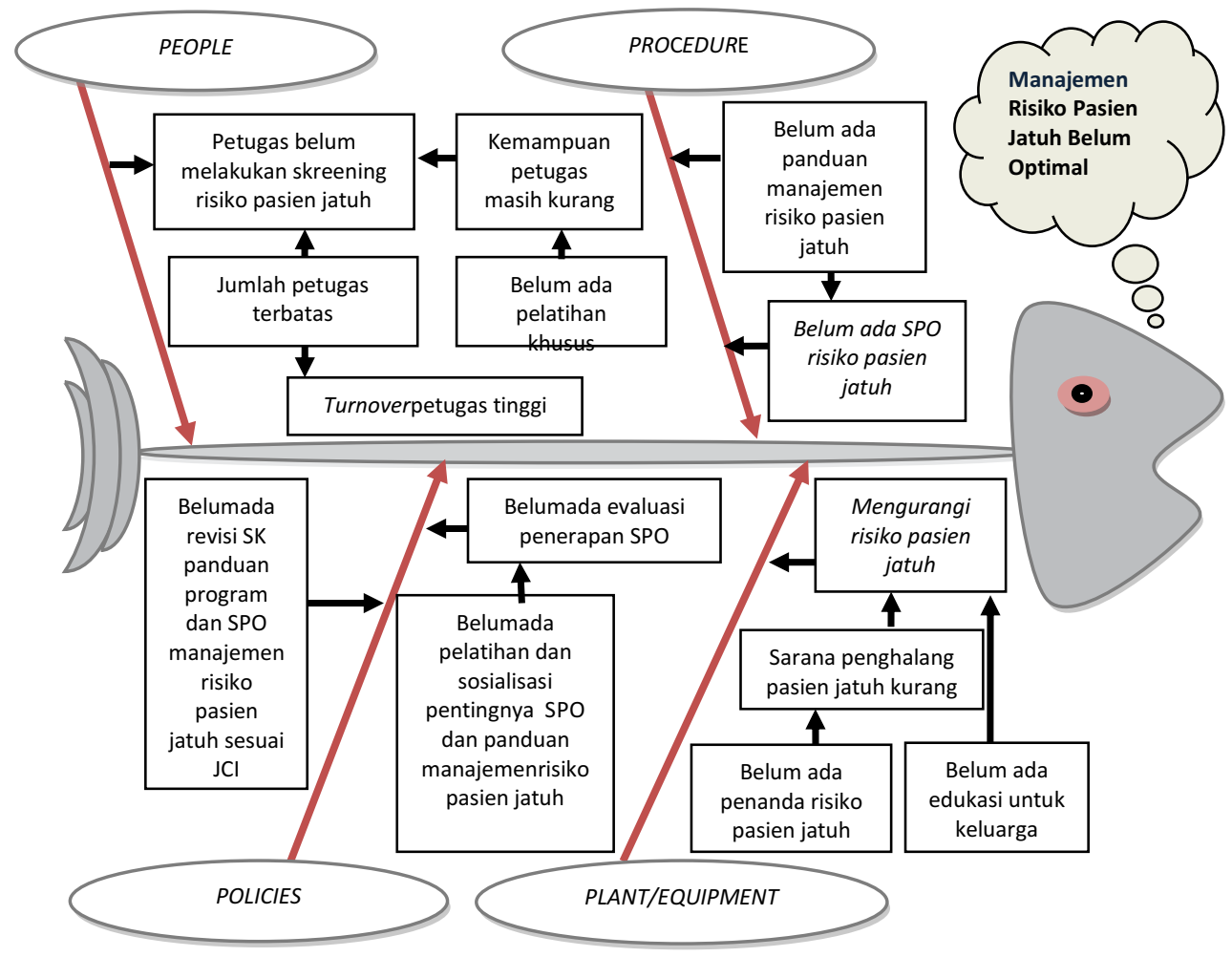

Gambar 1. Fishbone analisis akar masalah belum optimalnya penerapan manajemen risiko jatuh 
Tabel 1. Alternatif Solusi belum optimalnya manajemen risiko pasien jatuh di Rumah Sakit Islam Unisma Malang tahun 2013

\begin{tabular}{|c|c|c|c|c|}
\hline \multirow{2}{*}{ Masalah } & \multirow{2}{*}{ Konfirmasi } & \multicolumn{3}{|c|}{ Alternatif Solusi } \\
\hline & & Mengadakan & Mengendalikan & Mendeteksi \\
\hline Procedure & $\begin{array}{l}\text { Belum di susun SPO dan Panduan } \\
\text { manajemen risiko pasien jatuh }\end{array}$ & $\begin{array}{l}\text { Menyusun SPO \& Panduan } \\
\text { penerapan manajemen pasien } \\
\text { risiko jatuh }\end{array}$ & - & - \\
\hline \multirow[t]{2}{*}{ People } & $\begin{array}{l}\text { Petugas belum melakukan screning } \\
\text { risiko pasien jatuh }\end{array}$ & - & $\begin{array}{l}\text { Memaksimalkan petugas untuk } \\
\text { screeningrisiko pasien jatuh }\end{array}$ & - \\
\hline & $\begin{array}{l}\text { Kemampuan petugas masih kurang, } \\
\text { belum ada pelatihan khusus risiko } \\
\text { pasien jatuh }\end{array}$ & $\begin{array}{l}\text { Melaksanakan pelatihan } \\
\text { penerapan program dan SPO (in } \\
\text { house training) }\end{array}$ & - & - \\
\hline \multirow[t]{2}{*}{ Policies } & $\begin{array}{l}\text { Belum ada revisi SK Direktur } \\
\text { tentang SPO manajemen risiko } \\
\text { pasien jatuh sesuai JCI }\end{array}$ & $\begin{array}{l}\text { Mendapatkan revisi SK Direktur } \\
\text { tentang program manajemen } \\
\text { pasien risiko jatuh sesuai JCl }\end{array}$ & - & - \\
\hline & $\begin{array}{l}\text { Belum ada sosialisasi pentingnya } \\
\text { SPO, panduan dan kebijakan } \\
\text { manajemen risiko jatuh }\end{array}$ & $\begin{array}{l}\text { Melakukan sosialisasi tentang } \\
\text { penerapan program manajemen } \\
\text { risiko pasien jatuh }\end{array}$ & - & - \\
\hline \multirow[t]{3}{*}{$\begin{array}{l}\text { Plan/ } \\
\text { Equipment }\end{array}$} & $\begin{array}{l}\text { Sarana pengahalang risiko pasien } \\
\text { jatuh masih kurang }\end{array}$ & - & $\begin{array}{l}\text { Merencanakan sarana } \\
\text { penghalang risiko pasien jatuh }\end{array}$ & - \\
\hline & $\begin{array}{l}\text { Belum ada penanda yang melekat } \\
\text { pasien risiko jatuh }\end{array}$ & $\begin{array}{l}\text { Membuat penanda pasien risiko } \\
\text { jatuh (gelang Kuning) }\end{array}$ & - & - \\
\hline & $\begin{array}{l}\text { Belum ada edukasi untuk keluarga } \\
\text { tentang risiko pasien jatuh }\end{array}$ & $\begin{array}{l}\text { Membuat leaflet edukasi kepada } \\
\text { pasien dan keluarga }\end{array}$ & - & - \\
\hline
\end{tabular}

Analisis teoritik model dilakukan dengan mengidentifikasi semua kemungkinan metode alternatif penyelesaian masalah yang dapat dilakukan pada tiap level akar masalah, dengan tujuan untuk menghilangkan, mengendalikan dan mendeteksi permasalahan. Alternatif solusi yang telah disepakati kemudian diterapkan sebagai bentuk uji coba dengan evaluasi pelaksanaan screening risiko jatuh pada bulan November 2013

\section{HASIL}

\section{Analisis Akar Masalah}

Hasil identifikasi proses akar masalah manajemen risiko pasien jatuh belum optimal terletak pada tingkat perencanaan, sehingga dalam menetapkan akar masalah dilakukan dengan analisis tulang ikan (fishbone) atau diagram Ishikawa. Hasil analisis menunjukkan bahwa sistem manajemen belum berjalan karena belum ditunjang dengan implementasi pada semua komponen yaitu pelaksana, standar operasional yang belum ditetapkan serta sarana yang tidak adekuat.

Berdasarkan identifikasi akar masalah dengan menggunakan diagram tulang ikan (fishbone) ditetapkan alternatif solusi pada tiap level masalah dengan tujuan menghilangkan, mengendalikan dan mendeteksi permasalahan (Tabel 1). Sebagian besar solusi bersifat baru karena belum ada atau upaya tersebut belum pernah dilakukan seperti penyusunan prosedur standar yang didukung SK, sosialisasi, penanda risiko dan edukasi pada keluarga. Keseluruhan program dilaksanakan dalam jangka waktu tiga bulan.

\section{Pembuatan Program dan Standar Prosedur Operasional} Manajemen Risiko Pasien Jatuh

Upaya yang dilakukan oleh peneliti beserta tim manajemen, khususnya tim Keselamatan Pasien Rumah Sakit (KPRS) adalah melakukan Focused Group Discussion (FGD) yaitu diskusi bersama secara terfokus pada topik penyusunan program manajemen pasien jatuh. FGD dilakukan oleh peneliti bersama tim KPRS, berdiskusi intensif dalam pembuatan program dan penyusunan standar prosedur operasional (SPO) serta intrumen yang digunakan dalam penerapan program. Hasil FGD yang dilakukan oleh peneliti dan tim KPRS selama 2 pekan yaitu tersusun dan di setujuinya pedoman pelaksanaan program kegiatan manajemen risiko pasien jatuh, instrumen identifikasi pasien risiko jatuh berupa penyusunan form screening pasien risiko jatuh, pembuatan penanda yang melekat pada diri pasien risiko jatuh (gelang identitas berwarna kuning), pembuatan leaflet edukasi pasien dan keluarga tentang penanganan risiko pasien jatuh, sosialisasi dan pelatihan petugas tentang manajemen risiko pasien jatuh. Semua program tersebut harus ditunjang dengan penyusunan standar prosedur operasional (SPO) manajemen risiko pasien jatuh yang terdiri dari SPO screening pasien risiko jatuh, SPO pemasangan gelang identitas risiko jatuh, SPO edukasi kepada pasien dan keluarga tentang risiko jatuh, SPO pengelolaan pasien risiko jatuh, SPO penanganan pasien jatuh, SPO pelaporan Insiden Kejadian Pasien pelayanan keperawatan.

Program dan SPO yang telah tersusun kemudian di ajukan kepada Direktur untuk dikoreksi. Setelah dilakukan beberapa koreksi dan perbaikan maka direktur memberikan disposisi untuk dilakukan proses pengesahan dengan di keluarkannya Surat Keputusan (SK) pelaksanaan program manajemen risiko pasien jatuh di Rumah Sakit Islam Unisma Malang. Peneliti dan tim KPRS selanjutnya melakukan sosialisasi dan pelatihan penerapan program manajemen risiko pasien jatuh kepada seluruh anggota tim KPRS, para kepala ruangan dan kepala unit.

\section{Sosialisasi dan Pelatihan Program Manajemen Risiko Pasien Jatuh}

Sosialisasi dan pelatihan manajemen pasien risiko jatuh dilakukan untuk memberikan pengetahuan dan pemahaman kepada petugas, khususnya perawat dalam menunjang pelaksanaan program manajemen risiko 
pasien jatuh. Kegiatan sosialisasi dan pelatihan dilaksanakan selama satu hari kerja dengan dihadiri oleh 23 peserta terdiri dari anggota tim KPRS, kepala ruangan dan kepala unit, serta direktur.

Sosialisasi dan pelatihan dilakukan untuk mendorong partisipasi aktif dan memberikan kesempatan pada peserta untuk belajar. Metode pelatihan yang digunakan adalah: ceramah dan tanya jawab dengan presentasi. Bahan ceramah dikembangkan sesuai dengan pengalaman sehingga lebih praktis dan operasional. Ada tiga sesi ceramah dan diberikan oleh tiga narasumber, dengan topik manajemen risiko pasien jatuh sebagai titik tolak Patien Safety dalam menyongsong akreditasi rumah sakit versi 2012, pentingnya pedoman dan SPO manajemen risiko pasien jatuh, dan cara melakukan screening pasien risiko jatuh dan cara pengisian form screening risiko pasien jatuh. Selanjutnya selama dua pekan, seluruh kepala ruangan dan kepala unit melakukan sosialisasi dan mengajarkan kembali seluruh materi yang didapat kepada seluruh staf di ruangan dan seluruh unit masing-masing, sehingga seluruh staf juga dapat mengetahui dan paham terhadap program yang di jalankan. Pada dua pekan berikutnya mulai dilakukan penerapan manajemen risiko pasien jatuh, yang dalam pelaksanaannya dilakukan pemantauan oleh manajer keperawatan dan Tim KPRS Rumah Sakit Islam Unisma Malang.

\section{Pengadaan Sarana Edukasi Pasien Risiko Jatuh}

Pelaksanaan manajemen risiko pasien jatuh juga melibatkan keluarga atau penunggu pasien, mengajak keluarga untuk terlibat dan berperan aktif dalam pelaksanaan manajemen risiko pasien jatuh. Dalam pogram ini petugas atau perawat mengajarkan hal-hal atau tindakan yang dapat dilakukan untuk mencegah pasien terjatuh dalam bentuk kegiatan edukasi kepada pasien dan atau keluarga tentang risiko pasien jatuh dengan dibantu sarana berupa leaflet penanganan pasien risiko jatuh. Pembuatan leaflet edukasi dilakukan oleh peneliti bersama tim KPRS melalui proses diskusi. Setelah dilakukan penyusunan leaflet kemudian dilakukan proses uji coba dan dalam proses uji coba ini ada beberapa perbaikan terhadap materi dan isi dari leflet tersebut untuk selanjutnya dicetak.

\section{Penerapan Instrumen dan Standar Prosedur Operasional Manajemen Risiko Pasien Jatuh}

Pelaksanaan uji coba penerapan program manajemen risiko pasien jatuh dilakukan selama dua pekan dengan menggunakan instrumen yang telah disiapkan dan berdasarkan standar prosedur operasional (SPO) di seluruh ruang rawat inap Rumah Sakit Islam Unisma Malang. Hasilnya perawat di ruang rawat inap telah melaksanakan manajemen risiko pasien jatuh sesuai pedoman dan SPO yang ditetapkan.

Pelaksanaan screening pasien risiko jatuh di lakukan oleh perawat dengan menggunakan form screening pasien risiko jatuh terdiri dari tiga yaitu Morse Fall Scale (MFS) untuk pasien dewasa (7). Humpty dumpy scale untuk pasien anak dan ceklist pengkajian jatuh usia lanjut/orang tua. Pasien dengan hasil screening berisiko jatuh akan diberikan penanda yang melekat pada diri pasien dengan menggunakan gelang identitas risiko jatuh berwarna kuning. Hasil menunjukkan bahwaselama 2 pekan penerapan instrumen, perawat telah melakukan screening pasien risiko jatuh terhadap pasien baru rata- rata sebesar $26,5 \%$ dengan trend meningkat. Hal ini masih terlihat kecil di sebabkan karena perawat belum terbiasa melakukan screening pasien risiko jatuh dan sarana berupa gelang risiko belum tersedia karena masih dalam proses pemesanan. Untuk sementara digunakan stiker risiko jatuh yang ditempel pada gelang identitas pasien. Pelaksanaan program manajemen risiko jatuh ditunjang dengan perencanaan ketersediaan sarana dan prasarana pendukung yang memadahi dalam pemenuhan standar keselamatan pasien (patient safety) seperti pemenuhan semua tempat tidur berpengaman, pemasangan bel di tempat tidur.

Tabel 2. Hasil uji coba penerapan instrumen screening pasien risiko jatuh

\begin{tabular}{cccc}
\hline Hari & Pasien Baru & Pasien di Screening & Persentase \\
\hline 1 & 13 & 3 & 23,1 \\
2 & 11 & 2 & 18,2 \\
3 & 9 & 2 & 22,2 \\
4 & 16 & 4 & 25,0 \\
5 & 12 & 3 & 25,0 \\
6 & 14 & 2 & 14,3 \\
7 & 14 & 3 & 21,4 \\
8 & 16 & 4 & 25,0 \\
9 & 13 & 4 & 30,8 \\
10 & 12 & 4 & 33,3 \\
11 & 11 & 3 & 27,3 \\
12 & 6 & 2 & 33,3 \\
13 & 8 & 5 & 62,5 \\
Jumlah & 155 & 41 & 26,5 \\
\hline
\end{tabular}

Sumber: Data Rekam Medis RSI Unisma Malang (10)

\section{PEMBAHASAN}

Keamanan adalah prinsip yang paling fundamental dalam pemberian pelayanan kesehatan maupun keperawatan, dan sekaligus aspek yang paling kritis dari manajemen kualitas. Keselamatan pasien (patient safety) adalah suatu sistem dimana rumah sakit membuat asuhan pasien lebih aman, mencegah terjadinya cidera yang disebabkan oleh kesalahan akibat melaksanakan suatu tindakan atau tidak mengambil tindakan yang seharusnya diambil (8). Upaya-upaya untuk mengurangi kejadian pasien jatuh di rumah sakit telah banyak dilakukan. Hal ini seperti di rangkum oleh Miake-Lye et al diantaranya: pendidikan pada pasien, pemberian tanda berisiko pada bed pasien dan pelatihan pada para staf merupakan intervensi yang paling efektif untuk mengurangi kejadian pasien jatuh. Lebih lanjut dalam proses implementasi intervensiintervensi di atas, dibutuhkan struktur organisasi yang baik, infrastruktur keamanan yang baik, budaya keselamatan pasien, kerja tim dan leadership (8).

Pelaksanaan program kegiatan manajemen risiko pasien jatuh merupakan upaya yang dilakukan untuk mencegah maupun menangani pasien dengan risiko jatuh maupun pasien yang mengalami insiden jatuh di Rumah Sakit Islam Unisma Malang. Perawat sebagai anggota inti tenaga kesehatan yang jumlahnya terbesar di rumah sakit (sebesar 40-60\%) dan pelayanan keperawatan yang diberikan merupakan bagian integral dari pelayanan kesehatan, memiliki peran kunci dalam mewujudkan keselamatan pasien (9). Perawat pada ruang rawat inap Rumah Sakit Islam Unisma Malang dengan latar belakang 
pendidikan Diploma III Keperawatan dan S1Keperawatan sudahdapat menerapkan dengan baik Standar Prosedur Operasional (SPO) manajemen risiko pasien jatuh. Hal ini diketahui bahwa perawat sudah melakukan screening terhadap pasien baru dengan menggunakan form screening yang telah tersedia. Apabila ditemukan pasien dengan hasil screening dengan skor berisiko jatuh maka perawat akan memberikan tanda risiko jatuh dengan memasangkan gelang identitas risiko jatuh berwarna kuning, selanjutnya pasien akan di tangani sesuai penyakitnya dan penanganan risiko jatuh sesuai standar proseduroperasional.

Perawat di ruangan juga sudah memahami dan melaksanakan tanggung jawab dalam hal memberikan informasi atau edukasi pada pasien dan keluarga tentang kemungkinan risiko jatuh, serta telah memberikan leaflet penanganan risiko pasien jatuh yang telah disediakan. Setiap haridengan pembagian 3 shift, perawat ruangan di Rumah Sakit Islam Unisma Malang selalu melihat perkembangan dari kesehatan pasien, dan jika ada perubahan kearah lebih baik ataupun kurang baik, maka perawat akan melakukaan penilaian ulang terhadap risiko jatuh dan akan mendokumentasikan hasilnya kedalam rekam medis pasien.

Dari hasil pengamatan selama uji coba penerapan instrumen diperoleh hasil bahwa rata-rata $26,5 \%$ perawat di Rumah Sakit Islam Unisma Malang telah melaksanakan screening pasien risiko jatuh. Apabila perawat menemukan pasien dengan risiko sedang dan risiko tinggi maka pasien akan di pasang gelang identitas risiko jatuh, yang selanjutnya akan diberikan edukasi kepada pasien dan keluarga tentang pasien risiko jatuh, serta dilakukan penanganan sesuai dengan pengelolaan pasien risiko jatuh, penanganan pasien jatuh dan pelaporan insiden pasien jatuh. Perawat di ruang rawat inap sudah cukup baik dalam menerapkan standar prosedur operasional (SPO). Hasil observasi memperlihatkan bahwa perawat senantiasa memperhatikan faktor lingkungan dan faktor pasien dalam memberikan pelayanan.

Faktor lingkungan diantisipasi dengan mengadakan rondelingkungan di tiap-tiap bagian, dimana pada ronde lingkungan akan ditemukan hal-halyang mungkin akan menjadi risiko untuk terjadinya jatuh. Tindakan keperawatan yang dilakukan perawat di ruang rawat inap Rumah Sakit Islam Unisma Malang dalam mencegah pasien untuk tidak jatuh adalah melakukan hal-hal sebagai berikut: (a) selalu meninggalkan tempat tidur dengan posisi horizontal terendah (untuk tempat tidur dengan ketinggian yang bisa diubah-ubah), (b) memasang penghalang tempat tidurdanmemeriksakeamanannya,(c) memeriksa dan menyesuaikan objek-objek yang menonjol seperti roda tempattidur, (d) membersihkan dan memindahkan alat-alatyang tidak dibutuhkan lagi, (e) menganjurkan untuk menggunakan pegangan sepanjang dinding koridor pada saat berjalan, (f) mengobservasi pasien dengan baik akan adanya tandakelemahan atau gaya berjalan yangtidakstabil, (g)memastikan bahwaada cukup cahaya (lamputidak dimatikan), terutama di waktu senja dan malam hari(10).

Faktor pasien yang menjadi perhatian perawat ruang rawat inap di Rumah Sakit Islam Unisma Malangantara

\section{DAFTAR PUSTAKA}

1. Yulia S. Pengaruh Pelatihan Keselamata Pasien terhadap Pemahaman Perawat Pelaksana Mengenai lain: obat yang digunakan pasien (multi pharmacy), penglihatan, perubahan status mental/perilaku pasien, kekurangan cairan dan elektrolit, kelemahan fisik atau anggota gerak, riwayat atau penyakit yang sedang diderita dan lainnya. Kegiatan yang dilakukan untuk mengantisipasi dan mencegah terjadinya pasien jatuh dengan atautanpa cidera perlu adanya pengkajian di awal maupun kemudian pengkajian ulang secara berkala mengenai risiko pasien jatuh, termasukrisiko potensial yang berhubungandengan jadwal pemberian obat serta mengambil tindakan untuk mengurangi semua risiko yang telah diidentifikasikan tersebut. Pengkajian risiko jatuh ini telah dapat dilaksanakan sejak pasien mulai mendaftar, yaitudengan menggunakan skala jatuh. Risiko jatuh dapat terjadi karenabeberapahal,diantaranya:salah memperkirakan jarak dari tempat tidur ke lantai, merasa lemah atau pusing pada saat mencoba untuk bangun, merubah posisi terlalu cepat dan kehilangan keseimbangan ketika mencobauntuk bangun darikursi. Hal ini umum terjadi khususnya pada pasien usialanjut, penyebab lain tidak meliputi tidak mengenal lingkungan sekelilingnya, meminum obat yang membuat kesadaran mereka terhadaplingkungan berkurang, beradaditempat gelap, gangguan status mental (misalnya: bingung atau disorientasi), gangguan mobilitas (misalnya: gangguan berjalan, kelemahan fisik, menurunnya mobilitas tungkai bawah, gangguan keseimbangan), riwayat jatuh sebelumnya, obat-obatan (sedatif dan penenang, obatobatan yang berlebihan), kerkebutuhan khusus dalam hal toileting (memerlukan bantuan untuk buang air, mengalami inkontinensia, diare, tidak dapat menahan keinginan buang air) dan usia lanjut (11).

Antisipasi dari faktor pasien salah satunya adalah melibatkan keluarga atau penunggu pasien dalam pencegahan terjadinya jatuh, mengajak untuk terlibat dan berperan aktif. Mengajarkan hal-hal atau tindakan yang dapat dilakukan untuk mencegah pasien jatuh, misalnya tidak meninggalkan pasien sendiri, menutup pengaman tempat tidur dan anjurkan keluarga untuk memberitahukan perawat bilaakan meninggalkan pasien. Segala upaya pencegahan jatuh telah perawat lakukan dalam upaya meminimalkan dan tidak terjadinya pasien jatuh di Rumah Sakit Islam Unisma Malang.

Penilaian terhadap pasien risiko jatuh diharapkan dapat mengurangi risiko jatuh dan meningkatkan kewaspadaan terhadap pasien berisiko jatuh. Dengan mengenali risiko jatuh maka akan dapat diprediksi risikojatuh seseorang, dan dilakukan tindakan pencegahan yang sesuai. Oleh karena itu, memahami risiko jatuh, melakukan tindakan pencegahan, dan penanganan pasien jatuh, merupakan langkah yang harus dilakukan untuk menurunkan risiko jatuh dan cidera pada pasien yang dirawat. Kegiatan manajemen risiko pasien jatuh ini terus dilaksanakan oleh seluruh petugas khususnya perawat dalam melakukan screening risiko jatuh terhadap semua pasien yang di rawat. $\mathrm{Hal}$ ini juga di tunjang dengan adanya hubungan pengetahuan perawat yang baik dengan pelaksanaan keselamatan pasien (patient safety) di ruang rawat inap. Penilaian ini menunjukkan bahwa penerapan manajemen pasien risiko memerlukan kebijakan, prosedur yang diikuti dengan supervisi dan monitoring.

Penerapan Keselamatan Pasien di RS Tugu Ibu Depok. [Tesis]. Universitas Indonesia, Depok. 2010.

2. Kementerian Kesehatan RI. Standar Akreditasi Rumah 
Sakit. Jakarta: Kementerian Kesehatan RI; 2011.

3. Departemen Kesehatan Republik Indonesia. Panduan Nasional Keselamatan Pasien Rumah Sakit. Jakarta: Departemen Kesehatan RI; 2008.

4. Rumah Sakit Islam Unisma Malang. Laporan Tahunan Rumah Sakit Islam Unisma Malang Tahun 2010. Malang: Rumah Sakit Islam Unisma Malang; 2011.

5. Rumah Sakit Islam Unisma Malang. Laporan Tahunan Rumah Sakit Islam Unisma Malang Tahun 2011. Malang: Rumah Sakit Islam Unisma Malang; 2012.

6. Rumah Sakit Islam Unisma Malang. Laporan Tahunan Rumah Sakit Islam Unisma Malang Tahun 2012. Malang: Rumah Sakit Islam Unisma Malang; 2013.

7. Barnett K. Reducing Patient Falls. January 2001March 2002. Dewsbury, England: Mid Yorkshire
Hospitals NHS Trust; 2008.

8. Miake-Lye IM Hempel S Ganz DA, and Shekelle PG. Inpatient Fall Prevention Programs as a Patient Safety Strategy: A Systematic Review. Annals of Internal Medicine. 2013; 158(5); 390-396.

9. Gillies DA. Nursing Management a System Approach. 3rd edition. Philadelphia: WB Saunders; 2007.

10. Oliver D, Daly F, Martin FC, and McMurdo ME. Risk Factors and Risk Assessment Tools for Falls in Hospital In-Patients: A Systematic Review. Age and Ageing. 2004; 33(2): 122-130.

11. Setyarini EA dan Herlina LL. Kepatuhan Perawat Melaksanakan Standar Prosedur Operasional Pencegahan Pasien Jatuh di Gedung Yosep 3 Dago dan Surya Kencana Rumah Sakit Borromeus. Jurnal Kesehatan STIKes Santo Borromeus. 2013; 94-105. 